\title{
CTLA4 Gene
}

National Cancer Institute

\section{Source}

National Cancer Institute. CTLA4 Gene. NCI Thesaurus. Code C28567.

This gene is involved in T-cell mediation and receptor signal transduction. 